\title{
16
}

\section{Sediment Transport in Grass Swales}

\author{
Yukio Nara and Robert E. Pitt
}

Grass swales are vegetated open channels that collect and transport stormwater runoff. They are often used as an alternative to concrete gutters to transport runoff along streets due to their low cost. However, they also offer several advantages in stormwater quality management, especially in their ability to infiltrate runoff. This chapter describes another benefit of grass swales: their ability to trap particulates during low flows. A series of detailed laboratory tests were conducted to describe sediment transport processes for stormwater grass swales. Field verifications of these processes are also described in this chapter. As expected, runoff hydraulics, especially depth of flow, along with swale length, affect the transport of particulates of different sizes. Shallow flows (less than the grass height) provided consistently high removal rates, while deeper flows (and especially along with relatively low sediment concentrations) had poorer sediment trapping abilities. Obviously, long swales and large particle sizes are an effective combination, but the smallest particles are likely to be effectively transported along most swales. There appeared to be equilibrium concentrations for different particle sizes that were not further reduced, irrespective of swale length, likely associated with combinations of scour of

Nara, Y. and R.E. Pitt. 2006. "Sediment Transport in Grass Swales." Journal of Water Management Modeling R225-16. doi: 10.14796/JWMM.R225-16.

(C) CHI 2006 www.chijournal.org ISSN: 2292-6062 (Formerly in Intelligent Modeling of Urban Water Systems. ISBN: 0-9736716-2-9) 
material from the underlying soil or of previously trapped sediment, and the carrying capacity of the water.

\subsection{Methodology}

The Department of Civil and Environmental Engineering at the University of Alabama has been conducting research investigating the effectiveness of grass swales for stormwater sediment transport for several years. This research was initially supported by the Water Environment Research Foundation (WERF) (Johnson, et al. 2003) and more recently by the University Transportation Center of Alabama (UTCA). The aims of this research are to understand the effects of different variables affecting sediment transport in grass swales, especially considering different particle sizes, swale features, and flow conditions.

Controlled tests were conducted using specially constructed indoor grass swales and test solutions having known concentrations of sediment with different particle sizes. The test solutions used particles of sieved sands (locally acquired) and commercially-sized silica (from U.S. Silica Co.). The indoor swales were adjusted for different slopes, and had three different grasses. Two series of indoor experiments were conducted. The first series were exploratory in nature to identify the most important variables affecting sediment transport, while the second series examined these variables in more detail and were used to develop a sediment transport model.

The first series of tests examined grass type, slope, swale length, time since the beginning of the flow, flow rate, particle size, and sediment concentration. The second series of tests focused on fewer grass types, had less variability in sediment concentrations, and composited samples over the complete test period. The sediment transport processes described in this chapter were derived during the second series of experiments.

The second series of indoor swale experiments included analyzing 108 samples for turbidity, total solids, total suspended solids, total dissolved solids, and particle size distribution. The results of the indoor swale experiments were verified during monitoring at an outdoor grass swale located adjacent to the Tuscaloosa (Alabama, U.S.A.) City Hall, during actual storm events. The outdoor swale tests included collecting and analyzing 69 samples during 13 storm events from August to December 2004. These samples were analyzed for turbidity, total solids, total suspended solids, total dissolved solids, and particle size distribution. 


\subsection{Indoor Experiments}

\subsubsection{Descriptions of the Experimental Set-up}

Experimental swales were constructed in an indoor greenhouse facility located in the Bevil building on the campus of the University of Alabama, as part of a prior research project (Johnson, et al. 2003). Artificial sunlight (ambient UV and visible) is provided, and room temperature is maintained at approximately $78^{\circ} \mathrm{F}\left(25^{\circ} \mathrm{C}\right)$ at this facility. The experimental set up consists of three identical rectangular channels on a base which is adjustable for varying channel slopes. A mixture of $70 \%$ top soil and $30 \%$ sand (by weight) was placed in the channel sections which are completely sealed by non-reactive marine-epoxy paint to prevent leakage. Each channel is $2 \mathrm{ft}$ wide $(0.6 \mathrm{~m}), 6 \mathrm{ft}$ long $(1.82 \mathrm{~m})$, and 6 in $(15 \mathrm{~cm})$ deep and has a specific type of lawn grass. Jason Kirby constructed these swales and tested the grasses for hydraulic resistance during his MSCE thesis (2003).

The swale system hydraulic components produced a well-mixed sheetflow two feet wide. The flow of the test mixture was controlled using a sediment slurry tank, a pump in a 150 -gallon $\left(0.57 \mathrm{~m}^{3}\right)$ tank, a mixing chamber, and a preliminary wooden chute, as shown in Figure 16.1. The sediment slurry tank constantly fed a mixture of test sediment into the mixing chamber where it was mixed with water pumped from the 150 -gallon $\left(0.57 \mathrm{~m}^{3}\right)$ tank before it flowed into the swale segment.

\subsubsection{Sediment Characteristics of the Sediment-water Mixture}

Fine-ground silica (SIL-CO-SIL ${ }^{\circledR}$ from US Silica Co.), along with sieved sands, were used in the test mixture. Fine-ground silicas obtained from U.S. Silica are naturally bright white, low in moisture, and chemically inert. Two different types of silca, SIL-CO-SIL $® 106$ and SIL-CO-SIL ${ }^{\circledR} 250$ were used. Sieved sands were used to provide larger particles, ranging from 90 to 250 $\mu \mathrm{m}$ and 300 to $425 \mu \mathrm{m}$. The sediment concentration of the test flow was set at $500 \mathrm{mg} / \mathrm{L}$, a concentration higher than for most stormwaters in order to obtain sufficient particles for accurate sizing during the tests. Table 16.1 shows the percentage contribution of the test sediments in different particle ranges, while Figure 16.2 shows the particle size distribution of the test sediment mixture. This mixture therefore had a wide range of particle sizes represented, enabling sediment transport processes to be described for several different size ranges that are represented in typical stormwaters. 


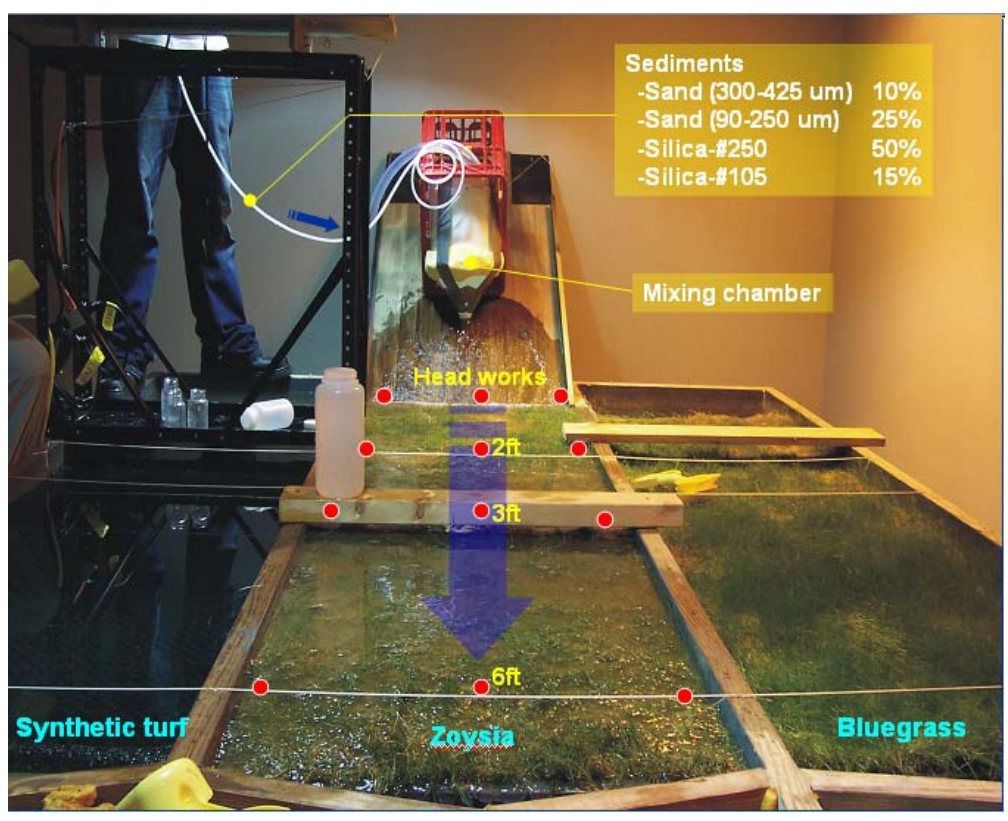

Figure 16.1 Overview of indoor experimental set-up.

Table 16.1 Percentage contribution and specific gravity of the test sediments.

\begin{tabular}{lcc}
\hline \multicolumn{1}{c}{ Sediment } & $\begin{array}{c}\text { Percentage } \\
\text { contribution }\end{array}$ & $\begin{array}{c}\text { Specific } \\
\text { gravity }\end{array}$ \\
\hline $\begin{array}{l}\text { Ground silica "flour" (SIL-CO- } \\
\left.\text { SIL }{ }^{\circledR} 106\right)\end{array}$ & $15 \%$ & 2.65 \\
Ground silica "flour" (SIL-CO- & $50 \%$ & 2.65 \\
SIL $^{\circledR} 250$ ) & $25 \%$ & 2.65 \\
Fine silica sand (90 to $250 \mu \mathrm{m})$ & $10 \%$ & 2.65 \\
Coarse silica sand (300 to $425 \mu \mathrm{m})$ & $100 \%$ & \\
\hline \multicolumn{1}{c}{ Total } & \\
\hline
\end{tabular}




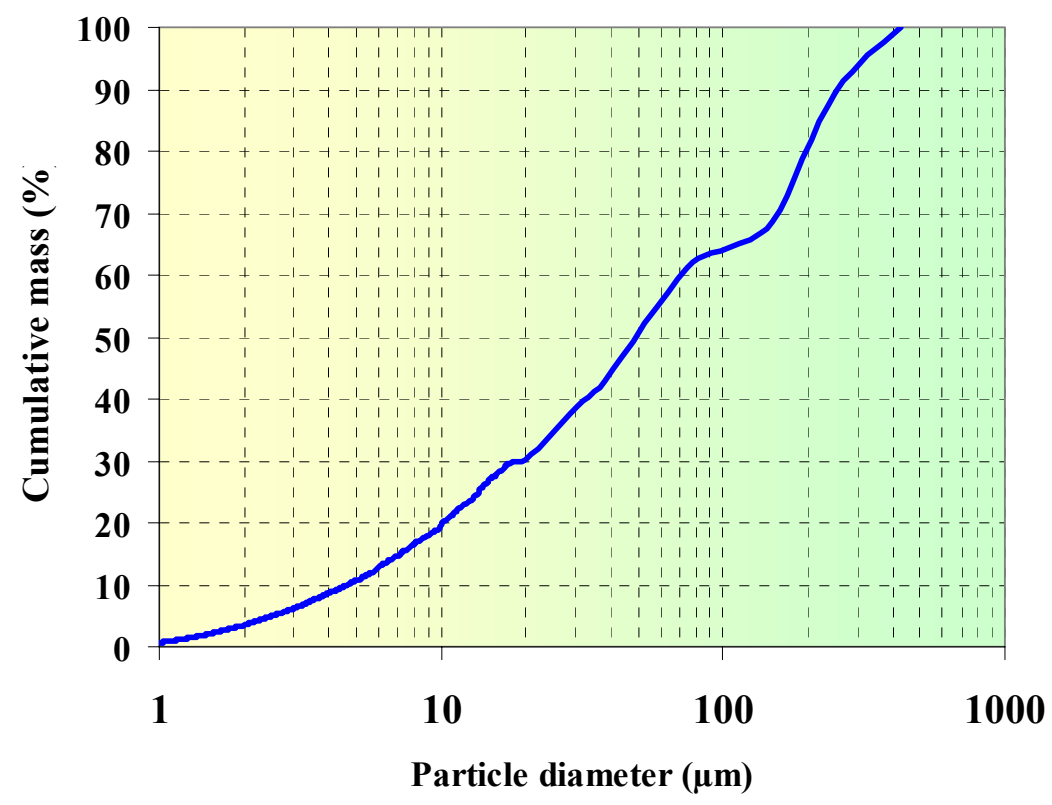

Figure 16.2 Particle size distribution of the composite test sediments mixture.

\subsubsection{Experimental Factors Tested During the Indoor Experiments}

Four main factors were tested during the second series of indoor experiments in order to quantify the effects of these variables on the transport of specifically-sized sediment in grass swales. These factors were grass type, slope, flow rate, and swale length:

- Grass types: The three different types of grass used were synthetic turf, Zoysia, and Kentucky bluegrass. Zoysia has a dense root structure that has high wear-tolerance, has a smooth and tough blade, and is commonly found in the Southern part of the United States. Kentucky bluegrass has smooth, upright stems and very fine blades. It is commonly found in the North and Midwest parts of the United States. The grass heights of both Zoysia and Kentucky bluegrass were maintained between 1.5 in $(3.8 \mathrm{~cm})$ to 2 in $(5 \mathrm{~cm})$ during the tests. The synthetic turf was obtained from a local 
warehouse store. The height of the blades of the synthetic turf was approximately 0.25 in $(0.63 \mathrm{~cm})$ which was much shorter than the other grass types. The blades are made of thin plastic and are uniformly dense.

- Slopes: $1 \%, 3 \%$, and $5 \%$ channel slopes were tested.

- Flow rates: Flow rates tested were 10 gallons per minute (GPM) $\left(0.038 \mathrm{~m}^{3} / \mathrm{min}\right), 15 \mathrm{GPM}\left(0.064 \mathrm{~m}^{3} / \mathrm{min}\right)$, and $20 \mathrm{GPM}(0.076$ $\left.\mathrm{m}^{3} / \mathrm{min}\right)$, in each of the $2 \mathrm{ft}(0.6 \mathrm{~m})$ wide swale sections.

- Swale length: Samples were collected at the head works $(0 \mathrm{ft})$, and $2 \mathrm{ft}(0.6 \mathrm{~m}), 3 \mathrm{ft}(0.9 \mathrm{~m})$, and $6 \mathrm{ft}(1.8 \mathrm{~m})$ from the head works.

\subsubsection{Results and Discussions}

During the second test series, 108 samples were collected and analyzed for the following analytical parameters:

1. Total solids (Standard Methods 2540B)

2. Total solids after screening with a $106 \mu \mathrm{m}$ sieve

3. Total suspended solids (solids retained on a $0.45 \mu \mathrm{m}$ filter) (Standard Methods 2540D)

4. Total Dissolved Solids (solids passing through a $0.45 \mu \mathrm{m}$ filter) (Standard Methods 2540C)

5. Turbidity using a HACH $2100 \mathrm{~N}$ Turbidimeter

6. Particle Size Distribution by Coulter Counter (Beckman ${ }^{\circledR}$ MultiSizer III $^{\mathrm{TM}}$ ), composite of several different aperture tube measurements

It was difficult to introduce consistent inlet concentrations during all of the experiments. Large particles in the 106 to $425 \mu \mathrm{m}$ size range had the largest overall variability due to the difficulty of consistently keeping the large particles suspended in the inlet water. Because of this variability, all concentration data were normalized against the initial sediment concentrations. Analysis of Variance (ANOVA) tests were performed to determine the effects of the experimental variables on these normalized concentration changes. However, residuals of the ANOVA tests were not normally distributed as required (normality confirmed using the AndersonDarling test). Therefore, for each swale length, the normalized data were ranked. The ANOVA test was then used on these ranked normalized data to determine the significance of the variables. 
Significant sediment reductions were observed at $2 \mathrm{ft}(0.6 \mathrm{~m}), 3 \mathrm{ft}(0.9 \mathrm{~m})$, and $6 \mathrm{ft}(1.8 \mathrm{~m})$ for total solids, total solids after screening with a $106 \mu \mathrm{m}$ sieve, total suspended solids, and turbidity. There were no significant changes in total dissolved solids as a function of swale length. Sediments were rapidly reduced between the head works $(0 \mathrm{ft})$ and $2 \mathrm{ft}(0.6 \mathrm{~m})$ due to large particle settlement at the beginning of the swale. After each experiment, sands were visually observed up to $1 \mathrm{ft}(0.3 \mathrm{~m})$ from the head works. Unlike solids, turbidity reductions were relatively constant with swale length since turbidity was not as affected by large particles.

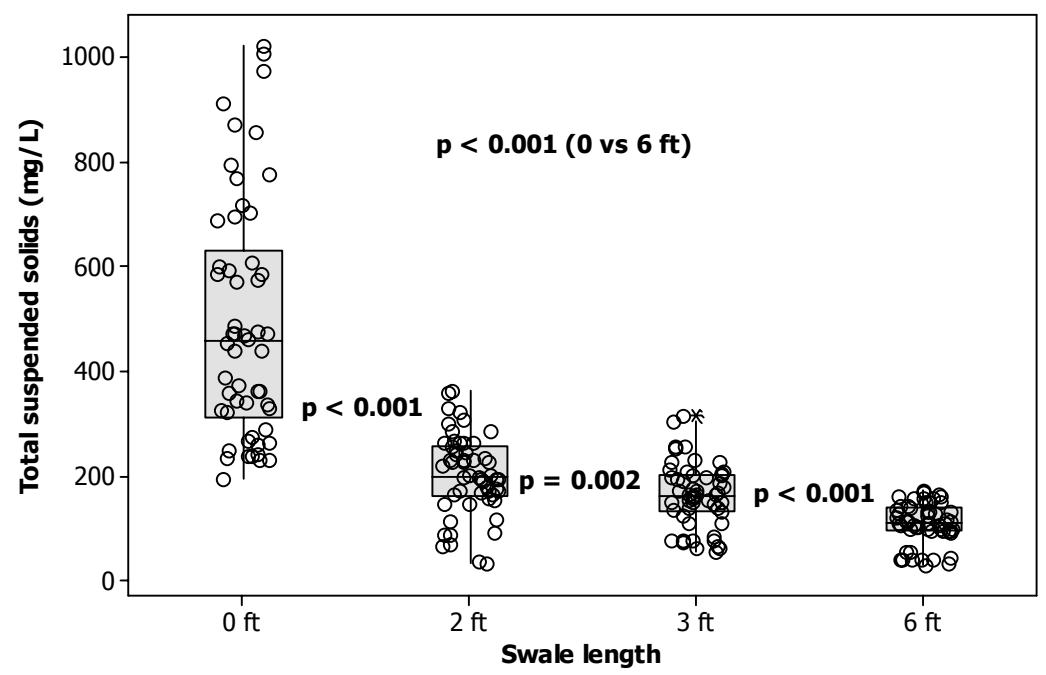

Figure 16.3 Box-and-whisker plots of total suspended solids concentrations vs. swale length (Note $1 \mathrm{ft}=0.30 \mathrm{~m}$ ).

All variables (swale length, grass type, slope, and flow rate) were found to be significant factors for most of the particulate constituents. In contrast, all variables were found to be insignificant for total dissolved solids. Among the three grass types, synthetic turf was found to be the least effective in trapping the sediment, and Zoysia and Kentucky blue grass had similar sediment reduction rates. The effects of channel slope and flow rate were marginal for total solids and total suspended solids. However, these effects were clearly significant for turbidity. $1 \%$ slope was found to be much more efficient in trapping the particulates than the 3\% and 5\% slopes, and the low flow rate of $10 \mathrm{GPM}\left(0.038 \mathrm{~m}^{3} / \mathrm{min}\right)$ was more effective in reducing 
turbidity than the higher flow rates of 15 GPM $\left(0.064 \mathrm{~m}^{3} / \mathrm{min}\right)$ and 20 GPM $\left(0.076 \mathrm{~m}^{3} / \mathrm{min}\right)$. Some of the interactions between the factors were also important and need to be considered when explaining sediment transport in grass swales. Table 16.2 shows the significant interaction terms and associated probabilities (p-values) for each constituent.

Table 16.2 Significant interaction factors and associated P-values.

\begin{tabular}{llc}
\hline Constituent & Interaction factor & P-value \\
\hline Total solids & Grass type * Slope & 0.023 \\
Total solids $(<106 \mu \mathrm{m})$ & Grass type * Flow rate & $<0.001$ \\
& Flow rate * Slope & $<0.001$ \\
Total suspended solids & Grass type * Flow rate & 0.005 \\
& Flow rate * Slope & 0.013 \\
Total dissolved solids & Grass type * Flow rate & 0.044 \\
Turbidity & Grass type * Slope & 0.001 \\
& Grass type * Flow rate & $<0.001$ \\
\hline
\end{tabular}

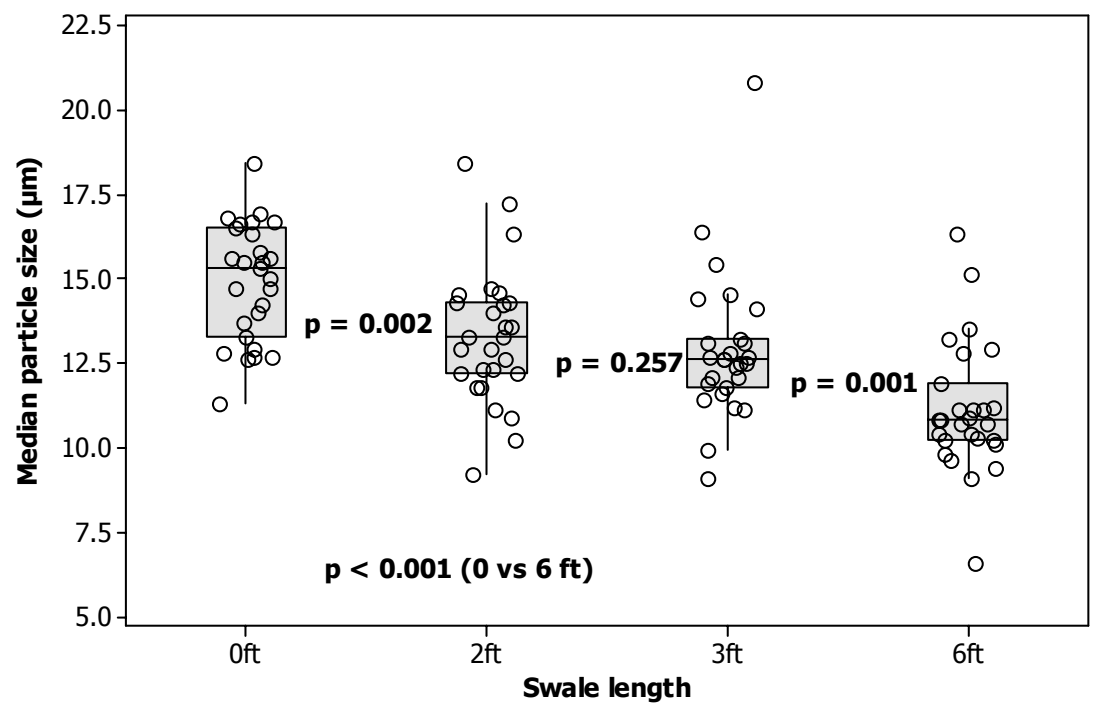

Figure 16.4 Box-and-whisker plots of median particle sizes vs. swale length $($ Note $1 \mathrm{ft}=0.30 \mathrm{~m})$. 
The swale length was found to be a significant factor affecting particle size distributions, while the three other factors (flow rate, slope, and grass type) were found to be insignificant. Figure 16.4 shows the median particle sizes of runoff particulates for each swale length. The median particle sizes consistently decreased by swale length, as expected, as the large particles were preferentially removed in the swale.

\subsection{Outdoor Swale Observations}

The indoor experiments were conducted to identify the significant factors affecting the transport of sediment in the grass swales, and to develop an associated model. The confirmation of the model obtained from the indoor experiments used sampling of stormwater at a full-size outdoor grass swale located adjacent to the Tuscaloosa, Alabama, City Hall during actual storm events. Sixty-seven samples were collected at various locations along the swale during 13 storm events from August to December 2004. These samples were analyzed for the same constituents as analyzed during the second indoor tests.

\subsubsection{Descriptions of the Site}

This full-sized swale has a length of $116 \mathrm{ft}(35.3 \mathrm{~m})$ and is covered with Zoysia grass. Although this is a full-sized swale, its drainage area is very small, only comprising 0.1 acres $\left(4,200 \mathrm{ft}^{2}\right.$ or $\left.390 \mathrm{~m}^{2}\right)$ of paved roads. Table 16.3 shows the channel slopes at various swale lengths. The slopes are steeper at the beginning of the swale and are flatter at the end.

Table 16.3 Channel slopes over various swale regions.

\begin{tabular}{lc}
\hline Swale region & Mean channel slope \\
\hline 0 to $5 \mathrm{ft}(0$ to $1.5 \mathrm{~m})$ & $5.2 \%$ \\
5 to $10 \mathrm{ft}(1.5$ to $3.0 \mathrm{~m})$ & $4.8 \%$ \\
10 to $70 \mathrm{ft}(3$ to $21.3 \mathrm{~m})$ & $3.0 \%$ \\
70 to $116 \mathrm{ft}(21.3$ to $35.3 \mathrm{~m})$ & $1.4 \%$ \\
\hline
\end{tabular}

A soil survey conducted at the outdoor swale found the soil to be compacted loamy sand in accordance with U.S. Department of Agriculture (USDA) Classification methods. In addition to surveying the slope and topsoil of the 
grass swale, infiltration rates of the swale were also measured using small double-ring infiltrometers (Turf-Tec, Inc). The infiltration tests were conducted during both dry and wet conditions. Most of the infiltration rates were much less than $1 \mathrm{in} / \mathrm{h}(2.54 \mathrm{~cm} / \mathrm{h})$, resulting in little runoff infiltration during the storm events. The detailed soil survey also found sediment accumulation at the head of the swale, with grass growing through the top of the accumulated sediments. During storm events, the accumulated sediment created a small puddle at the head of the swale preventing large particles from entering the swale due to initial sedimentation.

\subsubsection{Sample Collection and Analytical Methods}

A total of 67 samples were collected at $0 \mathrm{ft}, 2 \mathrm{ft}(0.6 \mathrm{~m}), 3 \mathrm{ft}(0.9 \mathrm{~m}), 6 \mathrm{ft}$ $(1.8 \mathrm{~m}), 25 \mathrm{ft}(7.6 \mathrm{~m}), 75 \mathrm{ft}(22.8 \mathrm{~m})$, and $116 \mathrm{ft}(35.3 \mathrm{~m})$ during 13 storm events from August 22, 2004 to December 8, 2004. However, not all events have a complete set of samples. During some events, runoff was insufficient at the time of sampling at specific locations for collecting a runoff sample.

The samples were analyzed for the following parameters:

1. Total solids (Standard Methods 2540B)

2. Total solids after sieving with a $106 \mu \mathrm{m}$ sieve

3. Total suspended solids (solids retained on a $0.45 \mu \mathrm{m}$ filter) (Standard Methods 2540C)

4. Total dissolved solids (solids passing through a $0.45 \mu \mathrm{m}$ filter) (Standard Methods 2540D)

5. Turbidity using a HACH $2100 \mathrm{~N}$ Turbidimeter

6. Particle Size Distribution by Coulter Counter (Beckman ${ }^{\circledR}$ MultiSizer III $^{\mathrm{TM}}$ ), composite of several different aperture tube measurements

All samples were split using a USGS/Dekaport cone splitter to ensure accurate divisions of the particulate-laden water before analyses.

\subsubsection{Results and Discussions}

While collecting samples, sediment reduction with increasing swale length was visually observed during most of the events. Figure 16.5 shows runoff samples and sediments captured on glass fiber filters at various swale lengths, collected on October 11, 2004. The sediments captured on filters, for samples obtained near the swale entrance, were solid black suggesting dusts from paved roads, while the color of sediment captured at $116 \mathrm{ft}$ 
$(35.3 \mathrm{~m})$ was light brown, primary caused by top soil erosion from the swale. It was clear that runoff sediments were captured as the stormwater passed through the grass swale, but soil erosion also occurred at longer swale distances.

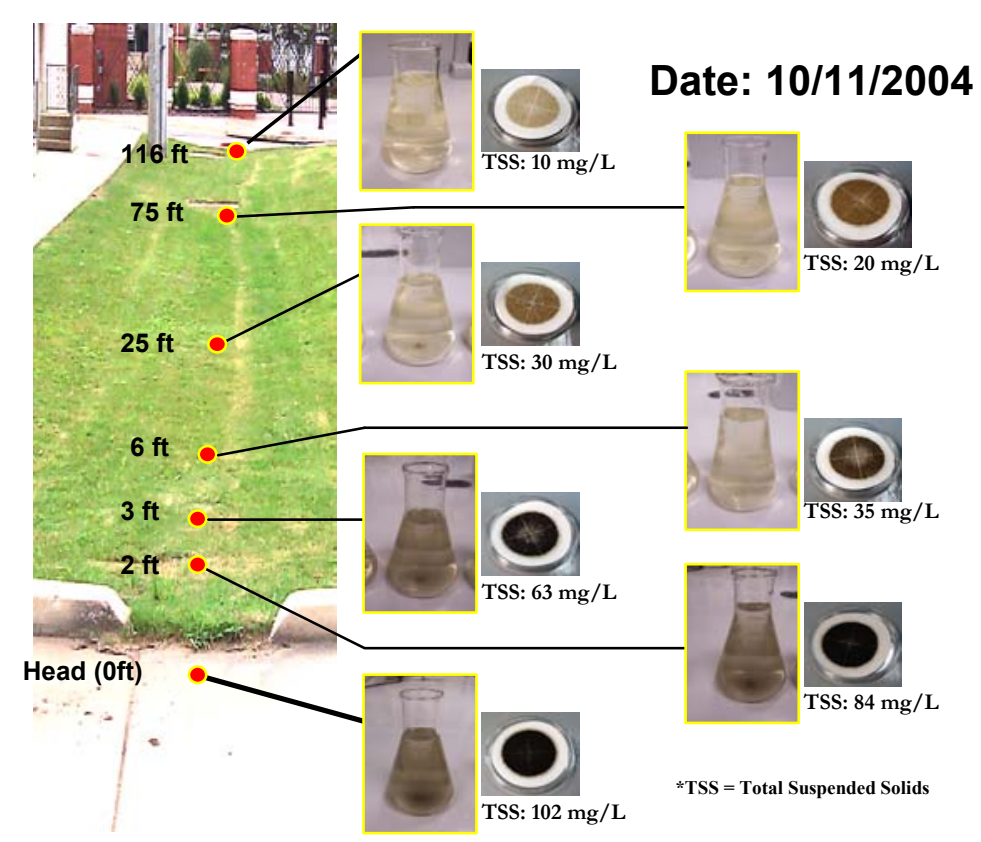

Figure 16.5 Sampling locations at the outdoor swale monitoring site (Example sediment samples from 10/11/2004).

\section{Total Suspended Solids}

Initial total suspended solids at the entrance of the swale varied during different rain events, ranging from $4 \mathrm{mg} / \mathrm{L}$ to $157 \mathrm{mg} / \mathrm{L}$. High sediment reductions were normally observed between $0 \mathrm{ft}$ and $25 \mathrm{ft}(7.6 \mathrm{~m})$. Beyond $25 \mathrm{ft}(7.6 \mathrm{~m})$, there was much less sediment reduction in the grass swale. During two events $(10 / 23 / 2004$ and 11/11/2004), total suspended solids increased between $0 \mathrm{ft}$ and $6 \mathrm{ft}(1.8 \mathrm{~m})$ instead of decreasing, likely due to scouring of previously deposited sediments at the entrance of the swale. An unusual sediment increase of $51 \mathrm{mg} / \mathrm{L}$ between $25 \mathrm{ft}(7.6 \mathrm{~m})$ and $75 \mathrm{ft}$ 
(22.8 m) was observed on 12/08/2004. During this sampling period, the rain intensity and runoff flow rate significantly increased after collecting the upgradient samples. The higher flow rate likely scoured the top soil of the swale, resulting in much higher TSS concentrations at $75 \mathrm{ft}(22.8 \mathrm{~m})$ than at $25 \mathrm{ft}(7.6 \mathrm{~m})$ during that event.

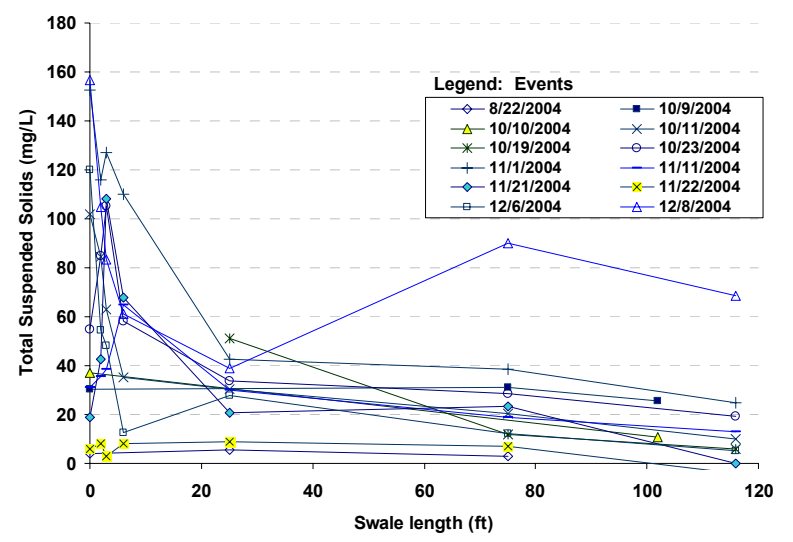

Figure 16.6 Total suspended solids concentrations vs. swale length, observed at the outdoor grass swale (Note $1 \mathrm{ft}=0.30 \mathrm{~m}$ ).

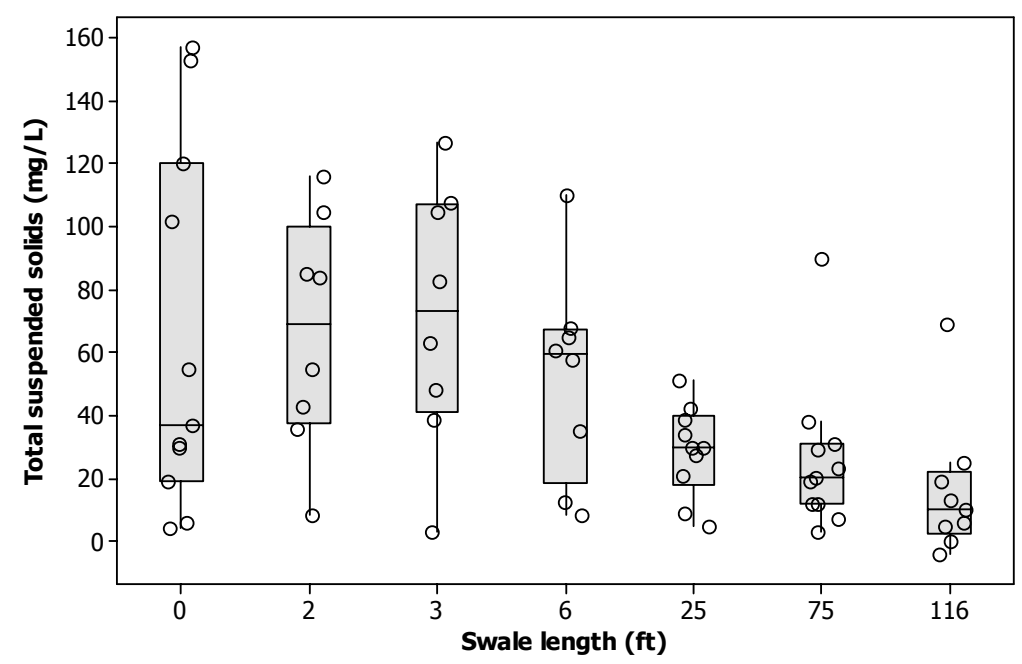

Figure 16.7 Box-and-whisker plots of total suspended solids concentrations vs. swale length observed at the outdoor grass swale (Note $1 \mathrm{ft}=0.30 \mathrm{~m}$ ). 
Figure 16.7 indicates that the concentrations were highly variable during the first three feet of the swale, significantly decreased between $3 \mathrm{ft}(0.9 \mathrm{~m})$ and $25 \mathrm{ft}(7.6 \mathrm{~m})$, and then decreased only slightly more to the end of the $116 \mathrm{ft}$ (35.3 m) swale.

\section{Turbidity}

Significant reductions in turbidity were observed at the outdoor swale. Although initial turbidity at the entrance ranged from 2 NTU to 137 NTU, all turbidity values (except on 12/08/2004) were reduced below $20 \mathrm{NTU}$ at $116 \mathrm{ft}(35.3 \mathrm{~m})$. Increased turbidity at $75 \mathrm{ft}(22.8 \mathrm{~m})$ on 12/08/2004 was due to scouring of the top soil during an intermittent period of high flows, as mentioned previously.

\section{Particle Size Distribution}

Observations at the outdoor swale confirmed that grass swales preferentially remove larger particles, as expected. Figure 16.9 shows that most of the median particle sizes are significantly reduced between $3 \mathrm{ft}(0.9 \mathrm{~m})$ and $25 \mathrm{ft}$ $(7.6 \mathrm{~m})$. However, there was no noticeable change in particle size between the swale entrance and $6 \mathrm{ft}(1.8 \mathrm{~m})$ due to possible scouring, and beyond 25 $\mathrm{ft}(7.6 \mathrm{~m})$ due to equilibrium concentrations being reached.

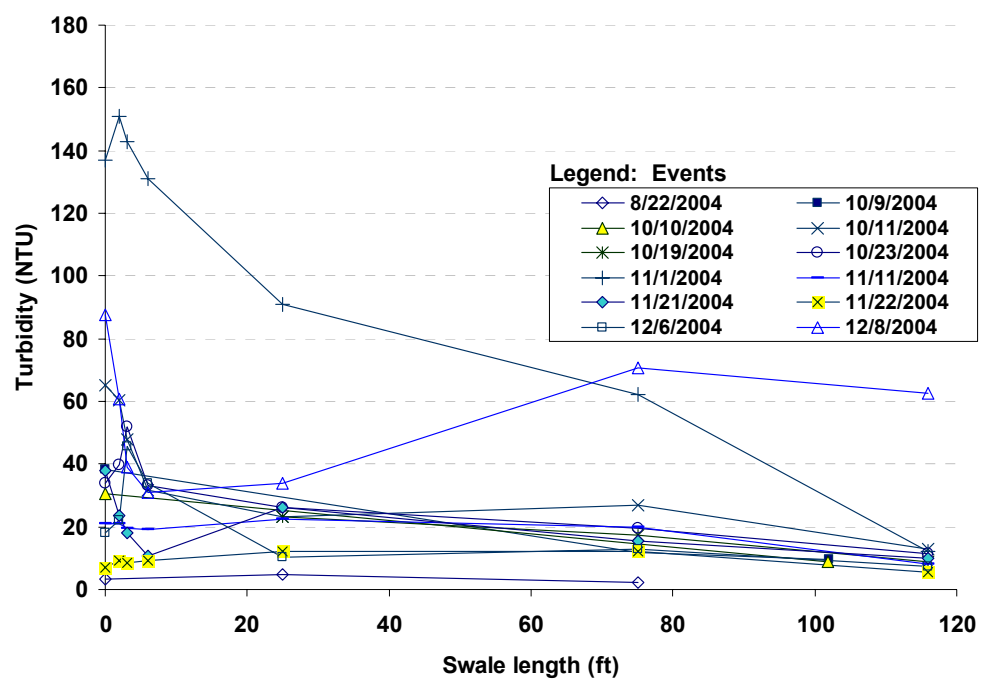

Figure 16.8 Turbidity vs. swale length, observed at the outdoor grass swale (Note $1 \mathrm{ft}=0.30 \mathrm{~m}$ ). 


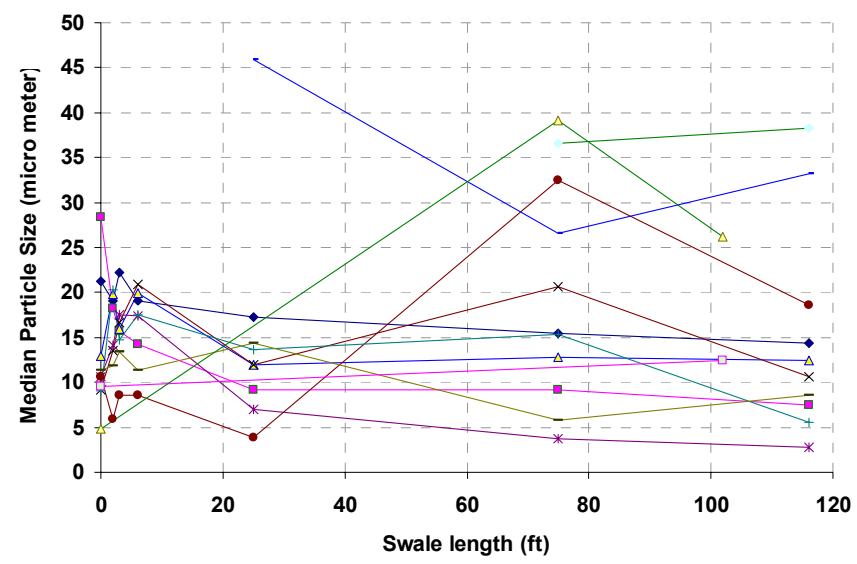

Figure 16.9 Median particle sizes vs. swale length observed at the outdoor grass swale (Note $1 \mathrm{ft}=0.30 \mathrm{~m}$ ).

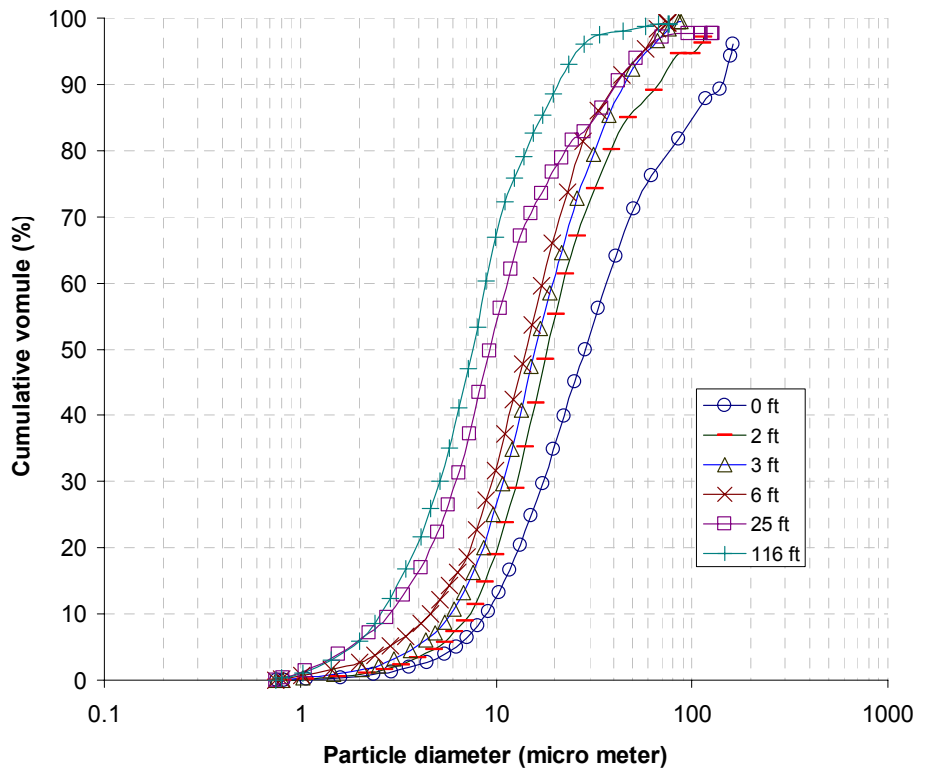

Figure 16.10 Example particle size distributions for different swale lengths observed on December 6, 2004. 


\subsection{Sediment Trapping Model Development and Verification}

The primary purpose of conducting the controlled indoor experiments was to develop a model that predicts sediment reduction of stormwater in actual grass swales. A model was developed using the analytical results (total solids, total solids less than $106 \mu \mathrm{m}$, total suspended solids, total dissolved solids, and particle size distribution analysis) obtained during the indoor experiment.

\subsubsection{Concepts}

During both the indoor experiments and the outdoor measurements, it was observed that sediment reductions were much higher at the beginning of the grass swales and then leveled off with flow distance. Thus, first order decay was applied to predict the reduction of runoff sediment as a function of swale length in order to normalize the effects of the different entrance sediment concentrations. The following is the first-order decay as applied to sediment transport in grass swales:

$$
\operatorname{Ln}\left(\frac{C_{\text {out }}}{C_{\text {in }}}\right)=-k t
$$

where:

$$
\begin{aligned}
\mathrm{C}_{\text {out }}= & \text { sediment concentration at down-gradient sampling } \\
& \text { locations } \\
\mathrm{C}_{\mathrm{in}}= & \text { initial sediment concentration at the swale entrance } \\
\mathrm{k}= & \text { first order constant } \\
\mathrm{t}= & \text { swale length in feet from the swale entrance }
\end{aligned}
$$

First-order constants (and associated percent reductions) were computed for each experimental test and observation. To understand sediment removal in grass swales, the constants and percent reductions were calculated for eight different particle size ranges:

$$
\begin{array}{ll}
\text { 1. } & <0.45 \mu \mathrm{m} \text { (total dissolved solids) } \\
\text { 2. } & 0.45 \text { to } 2 \mu \mathrm{m} \\
\text { 3. } & 2 \text { to } 5 \mu \mathrm{m} \\
\text { 4. } & 5 \text { to } 10 \mu \mathrm{m} \\
\text { 5. } & 10 \text { to } 30 \mu \mathrm{m}
\end{array}
$$



6. 30 to $60 \mu \mathrm{m}$
7. 60 to $106 \mu \mathrm{m}$
8. 106 to $425 \mu \mathrm{m}$

\subsubsection{Settling Frequency}

To incorporate the effects of particle sizes, swale length, flow depth and flow velocity on sediment transport, the number of chances particulates may theoretically settle in the grass swale was added to the sediment transport model. The number of chances particulates settle in a certain swale length is called "settling frequency." Settling frequency is computed using Stokes' law, considering length of swale and velocity, flow depth, and settling velocity of particles, is shown below.

Stokes' Law:

$$
V_{s}=\frac{2}{9} * \frac{\left(R^{2} * g *\left(P_{p}-P_{f}\right)\right)}{U}
$$

where:

$$
\begin{aligned}
V_{s}= & \text { Settling velocity of a particle }(\mathrm{cm} / \mathrm{s}) \\
R= & \text { Radius of a particle }(\mathrm{cm}) \\
g= & \text { Gravitational constant }=980 \mathrm{~cm} / \mathrm{s}^{2} \\
P_{p}= & \text { Density of a particle }=2.65 \mathrm{~g} / \mathrm{cm}^{3} \text { (assuming silica) } \\
P_{f}= & \text { Density of fluid }=1.0 \mathrm{~g} / \mathrm{cm}^{3} \text { (assuming water at } \\
& \text { standard } \\
& \text { temperature conditions) } \\
U= & \text { Dynamic viscosity }=0.01 \mathrm{~g} /\left(\mathrm{cm}^{*} \mathrm{~s}\right) \text { (assuming water } \\
& \text { at standard temperature conditions) }
\end{aligned}
$$

The time a certain particle requires to settle in a grass swale is therefore:

$$
\text { Settling_duration }=\frac{\text { flow_depth }}{\text { settling_velocity }}
$$

And the traveling time a certain particle takes from the beginning to the end of a swale is:

$$
\text { Traveling_time }=\frac{\text { swale_length }}{\text { flow_velocity }}
$$


Therefore:

$$
\text { Settling_frequency }=\frac{\text { traveling_time }}{\text { settling_duration }}
$$

\subsubsection{Predictive Model}

The relationship between flow depth and grass height was found to be very important since it considers flow rate, slope, and runoff contact area with the grass. To determine the effect of the flow depth/grass height ratio, averaged flow depth/grass height ratios were computed for each experimental condition. Then, percent reduction-settling frequency plots were created for three distinct flow depth/grass height ratio categories: 0 to $1.0,1.0$ to 1.5, and 1.5 to 4 . Ratios less than 1 means that the grass height is higher than the flow depth. Kirby (2003) determined Manning's roughness factors for these low flow conditions so the flow depth can be accurately calculated for these low flows. In addition to flow rates and the flow depth/grass height ratio, shear stress and slope were also examined to determine their significance on sediment trapping. It was found that shear stress and slope were insignificant factors. Therefore, settling frequency and the flow depth/grass height ratio were utilized for developing equations for modeling sediment reductions in grass swales. Initial sediment concentrations of the indoor swale experiments were much higher than the outdoor swale. Thus, the following sediment reduction equations are for high initial sediment concentrations (about $500 \mathrm{mg} / \mathrm{L}$ ) for different flow depth/grass height ratio ranges:

Flow depth/grass height ratio: 0 to 1.0

$$
Y=2.101 * \log (X)^{2}+6.498 * \log (X)+76.82
$$

where:

$$
\begin{aligned}
& Y=\text { Percent reduction } \\
& X=\text { Settling frequency } \\
& \begin{array}{lrrrrr}
\text { Analysis of } & \text { Variance } & & & \\
\text { Source } & \text { DF } & \text { SS } & \text { MS } & \text { F } & \text { P } \\
\text { Regression } & 2 & 10765.9 & 5382.93 & 32.98 & 0.000 \\
\text { Error } & 142 & 23177.0 & 163.22 & & \\
\text { Total } & 144 & 33942.8 & & &
\end{array}
\end{aligned}
$$




$\begin{array}{lrrrr}\text { Sequential Analysis of } & \text { Variance } & \\ \text { Source } & \text { DF } & \text { SS } & \text { F } & \text { P } \\ \text { Linear } & 1 & 7728.35 & 42.16 & 0.000 \\ \text { Quadratic } & 1 & 3037.51 & 18.61 & 0.000\end{array}$

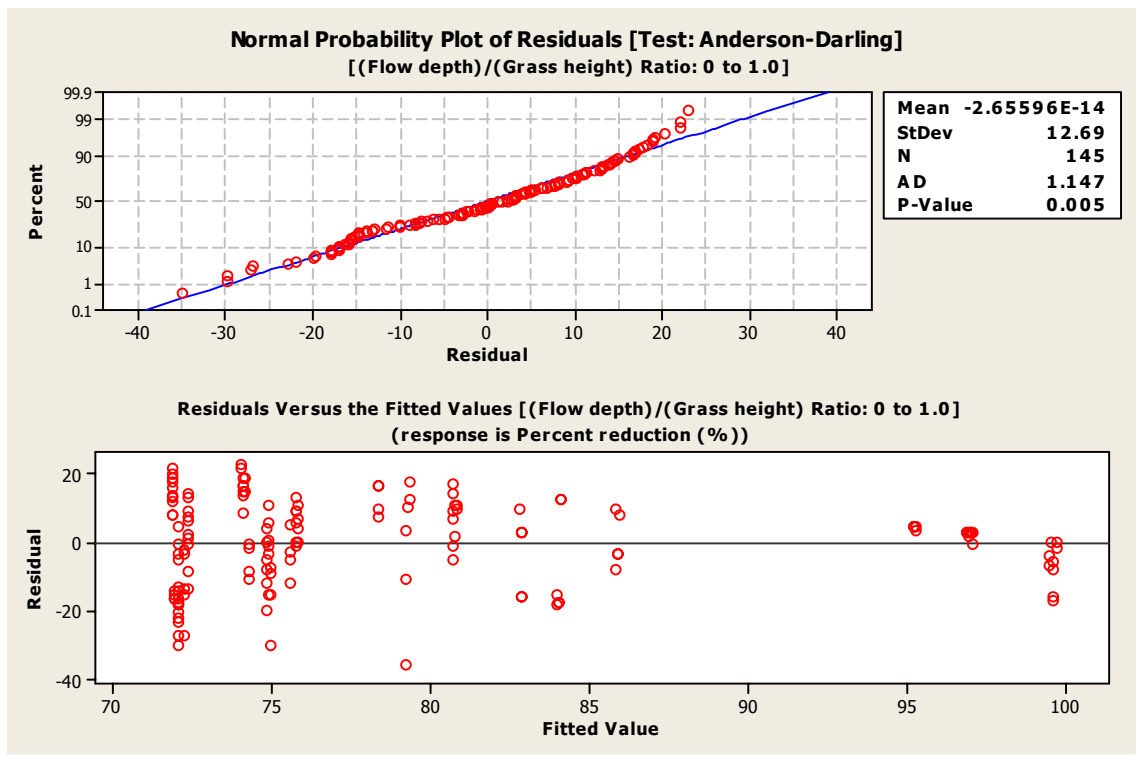

Figure 16.11 Normal probability plot and residual plot of the residuals vs. fitted values for the (flow depth)/(grass height) ratio between 0 to 1.0.

Flow depth/grass height ratio: 1.0 to 1.5

$$
Y=8.692 * \log (X)+80.94
$$

where:

$Y=$ Percent reduction

$X=$ Settling frequency

$\begin{array}{lrrrrr}\text { Analysis of } & \text { Variance } & & & \\ \text { Source } & \text { DF } & \text { SS } & \text { MS } & \text { F } & \text { P } \\ \text { Regression } & 1 & 9986.4 & 9986.44 & 44.36 & 0.000 \\ \text { Error } & 62 & 13957.0 & 225.11 & & \\ \text { Total } & 63 & 23943.5 & & & \end{array}$



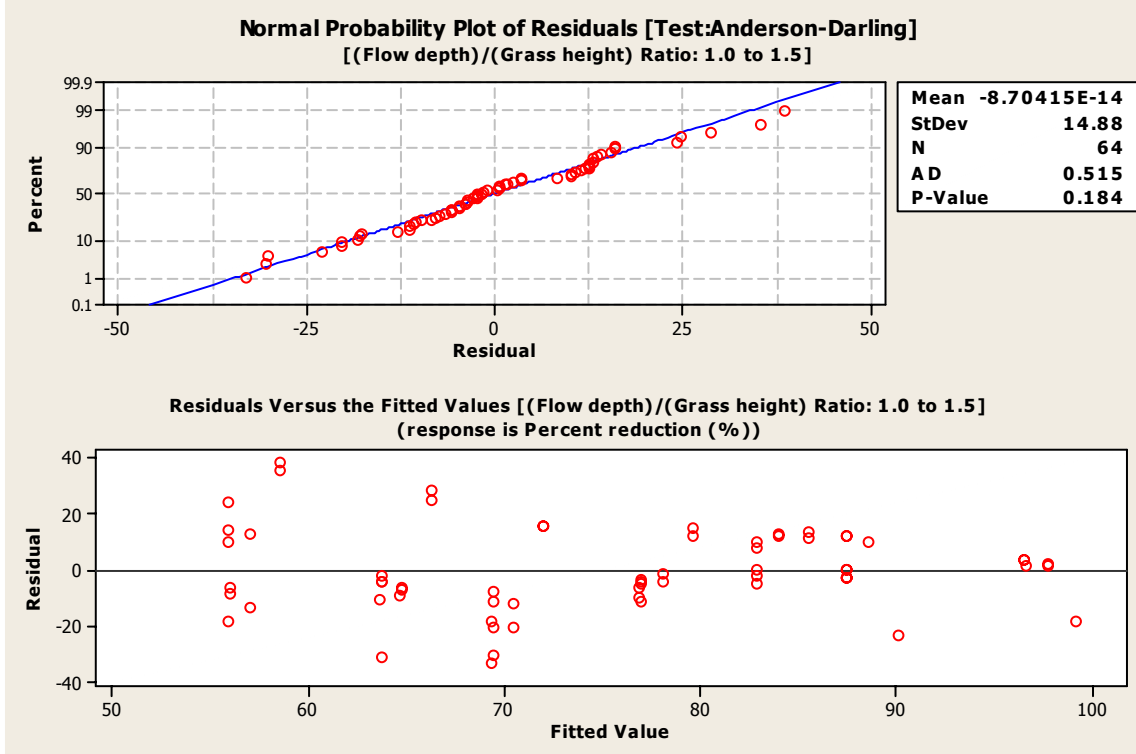

Figure 16.12 Normal probability plot and residual plot of the residuals vs. fitted values for the (flow depth)/(grass height) ratio between 1.0 to 1.5.

Flow depth/grass height ratio: 1.5 to 4.0

where:

$$
Y=2.382 * \log (X)^{2}+15.47 * \log (X)+67.46
$$

$Y=$ Percent reduction

$X=$ Settling frequency

$\begin{array}{lrrrrr}\begin{array}{l}\text { Analysis of Variance } \\ \text { Source }\end{array} & \text { DF } & \text { SS } & \text { MS } & \text { F } & \text { P } \\ \text { Regression } & 2 & 48358.8 & 24179.4 & 144.68 & 0.000 \\ \text { Error } & 131 & 21893.5 & 167.1 & & \\ \text { Total } & 133 & 70252.3 & & & \\ & & & & \\ \text { Sequential } & \text { Analysis } & \text { of } & \text { Variance } & \\ \text { Source } & \text { DF } & & \text { SS } & \text { F } & \text { P } \\ \text { Linear } & 1 & 45055.2 & 236.03 & 0.000 & \\ \text { Quadratic } & 1 & 3303.5 & 19.77 & 0.000 & \end{array}$




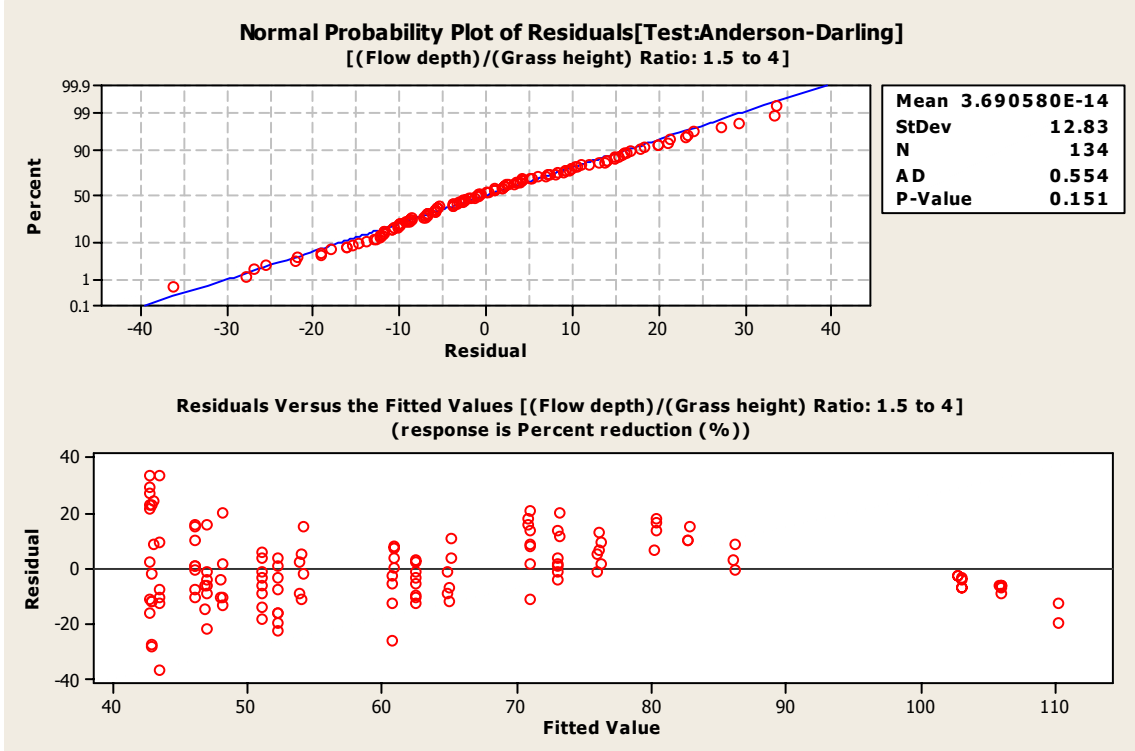

Figure 16.13 Normal probability plot and residual plot of the residuals vs. fitted values for the (flow depth)/(grass height) ratio between 1.5 to 4.0 .

Figures $16.11,16.12$, and 16.13 also show the residual plots. The residuals were found to be normally distributed, except for the flow depth/grass height ratio 0 to 1.0 due to several larger residuals at the extreme condition. Logtransformations on the percentage trapping values on the y-axis was attempted, however, they did not improve the distribution of residuals. Also, the variability of the residuals was smaller at higher percent reduction rates than for smaller rates. This is because the percent reduction values can not be greater than $100 \%$ although the settling frequency increases. Figure 16.14 shows the regression lines and 95\% confidence intervals of the three different flow depth/grass height ratios, and the percent reductions for total dissolved solids (particles $<0.45 \mu \mathrm{m}$ ). The percent reduction increases as the flow depth/grass height ratio decreases. This is especially true for lower settling frequencies, while the differences in the regression lines become negligible when the settling frequency is above 10 . 


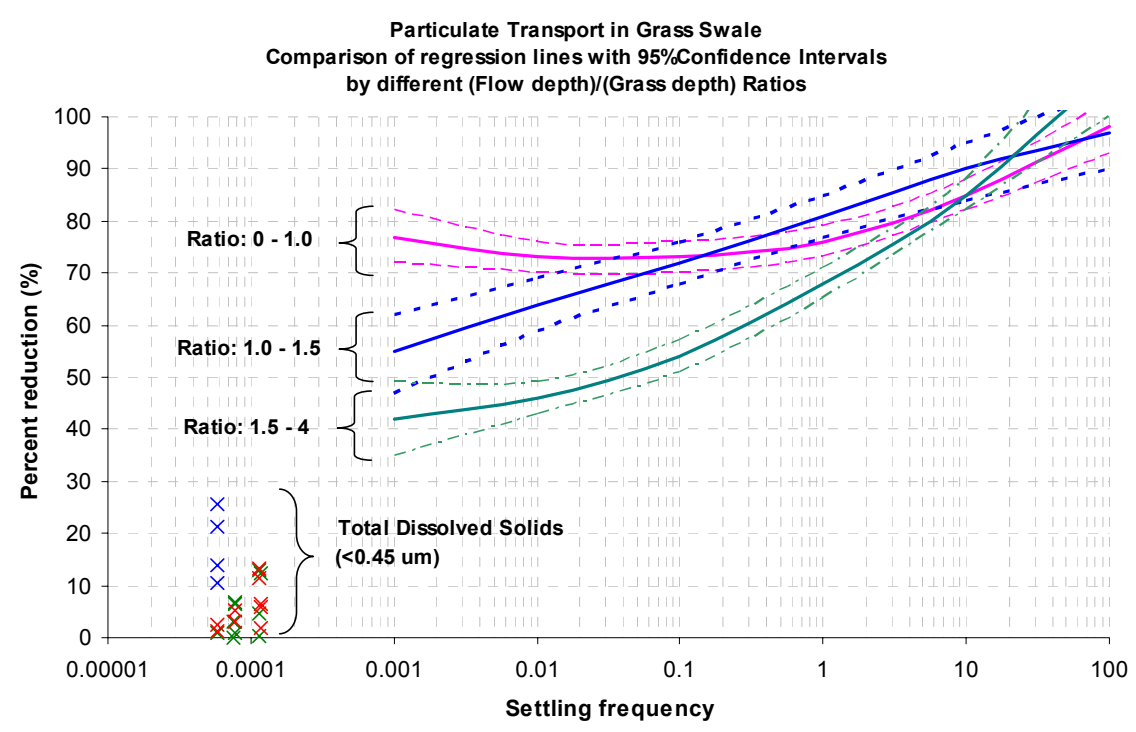

Figure 16.14 Comparison of regression lines with $95 \%$ confidence intervals for different (flow depth)/(grass height) ratios.

\subsubsection{Comparisons of Indoor and Outdoor Swale Observations}

Since the drainage area of the outdoor swale was very small, most of the events had shallow flows below the average grass height of 1 inch, which falls into the 0 to 1.0 flow depth/grass height ratio. Thus, the regression line and $95 \%$ confidence intervals of the indoor swale for 0 to 1.0 flow depth/grass height ratio were compared with the outdoor swale observations shown in Figure 16.15. There was a significant difference between the indoor and outdoor swale performances. The percentage reductions of particulates at the outdoor swale were much lower than for the indoor swale, especially for low settling frequencies. This was assumed to be primary due to the lower initial sediment concentrations at the outdoor swales (ranging from 4 to $157 \mathrm{mg} / \mathrm{L} \mathrm{TSS}$ ), compared to the initial sediment concentrations during the indoor swale experiments (ranging from $193 \mathrm{mg} / \mathrm{L}$ to $1,021 \mathrm{mg} / \mathrm{L}$ TSS). 


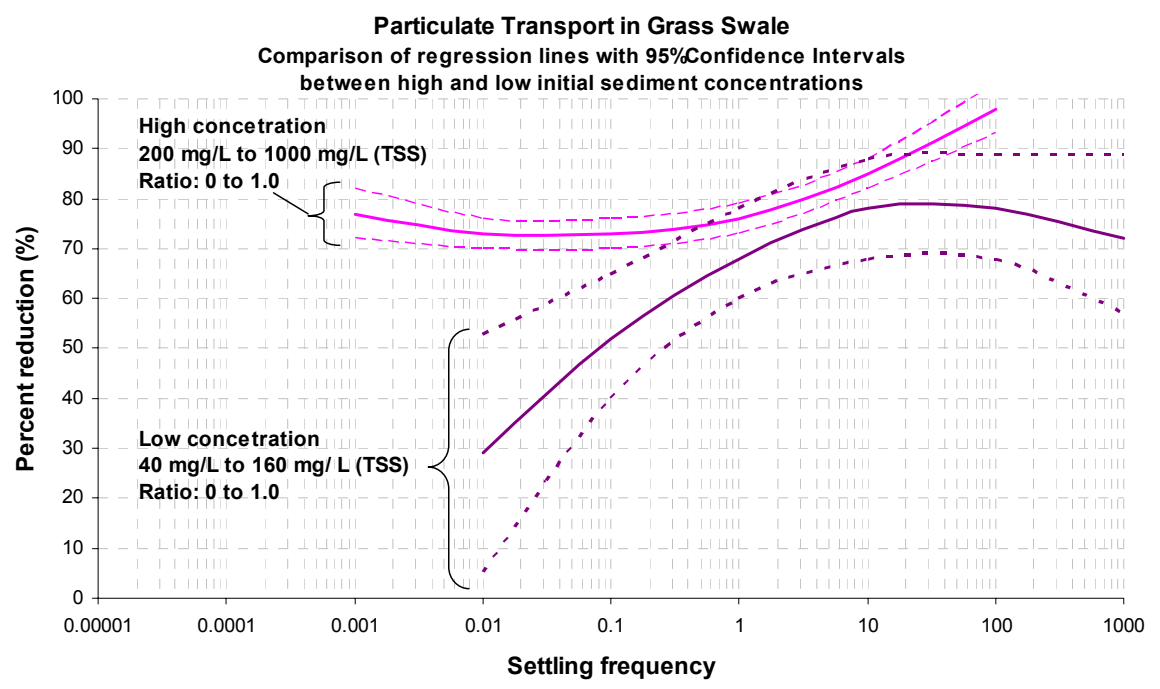

Figure 16.15 Regression lines with $95 \%$ confidence intervals for the low and high initial sediment concentrations (high concentrations from the second indoor experiment, average of $500 \mathrm{mg} / \mathrm{L}$, range of 200 to $1,000 \mathrm{mg} / \mathrm{L}$; low concentrations from the outdoor swale observations, average of $60 \mathrm{mg} / \mathrm{L}$, range of 10 to $160 \mathrm{mg} / \mathrm{L}$ ).

\subsection{Conclusions}

Compared with conventional concrete gutters, grass swales offer several advantages in stormwater quality management as well as cost efficiency. Grass swales are excellent for reducing stormwater pollutants by both infiltration and filtration, depending on the soil, grass, and flow conditions. In this chapter, sediment concentration reductions during shallow flows in grass swales were examined.

The indoor swale experiments revealed the significant factors affecting sediment transport in grass swales (swale length, grass type, channel slope, and runoff flow rate). Interactions between the factors were found to be important as well. Large particles, such as sands, were easily trapped at the beginning of the swales under most flow conditions, while smaller particles were more likely to be carried greater distances along the swales. Models for predicting sediment reductions were developed based on the particle settling frequency, and the flow depth/grass height ratio. 
Significant sediment reductions were observed in the grass swales. However, the outdoor swale monitoring revealed that sediment reductions also depend on initial sediment concentrations. Greater sediment reduction rates were observed for higher initial sediment concentrations.

\section{References}

Kirby, J.T. (2003). Determination of Vegetal Retardance in Grass Swales (Master thesis) the University of Alabama, Tuscaloosa, Alabama.

Johnson, P.D., R. Pitt, S.R. Durrans, M. Urrutia, and S. Clark (2003). Metals Removal

Technologies for Urban Stormwater. Water Environment Research Foundation.

WERF 97-IRM-2. ISBN: 1-94339-682-3. Alexandria, VA. 701 pgs. 
